\title{
Luteipulveratus mongoliensis gen. nov., sp. nov., an actinobacterial taxon in the family Dermacoccaceae
}

\author{
Correspondence \\ Ismet Ara \\ ara-ismet@nite.go.jp
}

\author{
Ismet Ara, ${ }^{1}$ Hideki Yamamura, ${ }^{2}$ Baljinova Tsetseg $^{3}{ }^{\text {Damdinsuren Daram }}{ }^{3}$ \\ and Katsuhiko Ando ${ }^{1}$
${ }^{1}$ Biotechnology Development Center, Department of Biotechnology, National Institute of Technology and Evaluation (NITE), Kazusakamatari 2-5-8, Kisarazu, Chiba, 292-0818, Japan
${ }^{2}$ Division of Applied Biological Sciences, Interdisciplinary Graduate School of Medicine and Engineering, University of Yamanashi, Takeda-4, Kofu 400-8511, Japan
${ }^{3}$ Institute of Biology, Mongolian Academy of Sciences, Ulaanbaatar-51, Mongolia

Mongolia is one of the largest Asian countries and is unique in its environmental traits. Recently, these environments have attracted the attention of naturalists and other researchers looking for novel actinomycetes (Norovsuren et al., 2007). In a programme aimed at isolating novel rare actinomycetes from Mongolia as a potential source of bioactive secondary metabolites, strain $\mathrm{MN} 07-\mathrm{A}_{0} 370^{\mathrm{T}}$, in the family Dermacoccaceae (Stackebrandt \& Schumann, 2000), was studied to establish its taxonomic status. The family Dermacoccaceae currently contains three recognized genera, Dermacoccus and Kytococcus (Stackebrandt et al., 1995) and Demetria (Groth et al., 1997a). Isolates assigned

Abbreviation: ISP, International Streptomyces Project.

The GenBank/EMBL/DDBJ accession number for the 16S rRNA gene sequence of strain MNO7-A0370 ${ }^{\top}$ is AB468971.

A supplementary table showing the cultural characteristics of strain MNO7-A0370 ${ }^{\top}$ is available with the online version of this paper. to this family are typically associated with terrestrial habitats, notably cured meat products, skin, human blood and soil (De la Rosa et al., 1990; Cordero \& Zumalacarregui, 2000; Becker et al., 2002; Papamanoli et al., 2002).

Samples of grassland soil were collected in July 2007 from Terelj National Park, Töv Province, Ulaanbaatar, Mongolia. The samples were dried at room temperature for 5-7 days, rehydrated and centrifuged (Hayakawa et al., 2000) and used to inoculate humic acid-vitamin agar (Hayakawa \& Nonomura, 1987) containing $\left(1^{-1}\right) 20 \mathrm{mg}$ trimethoprim and $10 \mathrm{mg}$ nalidixic acid. Strain MN07$\mathrm{A} 0370^{\mathrm{T}}$ was isolated after incubation for about 2 weeks at room temperature. The strain was then incubated on Bennett agar $(0.1 \%$ yeast extract, $0.1 \%$ beef extract; $0.2 \%$ $\mathrm{NZ}$ amine type $\mathrm{A} ; 1.0 \%$ maltose monohydrate, $1.5 \%$ agar; $\mathrm{pH}$ 7.3) (Jones, 1949) and yeast extract-soluble starch medium (YS medium; $1^{-1}: 2 \mathrm{~g}$ yeast extract, $10 \mathrm{~g}$ soluble 
starch, $15 \mathrm{~g}$ agar; $\mathrm{pH} 7.3$ ) at $28{ }^{\circ} \mathrm{C}$ for $10-14$ days and checked for purity.

The strain formed moist, raised, yellow colonies on Bennett and yeast-starch agars. Aerial mycelium was absent. A powdery, white, aerial mycelium-like formation was observed on International Streptomyces Project (ISP) media 3, 4, 5 and 7 after incubation for 2 weeks at $28{ }^{\circ} \mathrm{C}$. Spore motility was tested by observing cells suspended in phosphate buffer ( $1 \mathrm{mM}$; pH 7.0) under a light microscope. Morphological characteristics were observed using scanning electron microscopy as described by Tamura et al. (1994). The cultural characteristics of strain MN07-A0370 ${ }^{\mathrm{T}}$ were observed on ISP 2-7 media (Shirling \& Gottlieb, 1966), Bennett agar and YS medium after incubation at $28{ }^{\circ} \mathrm{C}$ for 3 weeks (see Supplementary Table S1, available in IJSEM online). Strain MN07-A0370 ${ }^{\mathrm{T}}$ showed good growth on all agar media tested.

DNA was extracted as described by Marmur (1961) and Saito \& Miura (1963) but with a slight modification: after lysis, $20 \%$ SDS (50 $\mu \mathrm{l})$ and proteinase $\mathrm{K}\left(50 \mu \mathrm{l}, 4 \mathrm{mg} \mathrm{ml}^{-1}\right.$, Nacalai Tesque) were used to denature and degrade proteins and phenol/chloroform/isoamyl alcohol $(25: 24: 1, \mathrm{v} / \mathrm{v})$ was used to remove denatured proteins. The 16S rRNA gene sequences were analysed as described by Tamura \& Hatano (2001), using an ABI Prism BigDye Terminator cycle sequencing kit (Applied Biosystems) and an automatic DNA sequencer (ABI Prism 3130 Genetic Analyzer; Applied Biosystems). The CLUSTAL_X program (Thompson et al., 1997) was used to align the 16S rRNA gene sequence with corresponding sequences from public databases for all of the type strains in the family Dermacoccaceae. The phylogenetic trees were inferred using the neighbour-joining method (Saitou \& Nei, 1987) in the CLUSTAL_X package and the neighbour-joining, minimum-evolution (Rzhetsky \& Nei, 1992) and maximum-parsimony (Eck \& Dayhoff, 1966) tree-making algorithms in the MEGA version 4 package
(Tamura et al., 2007). The evolutionary distances were computed using the maximum composite likelihood method (Tamura et al., 2004). The stability of the resultant tree topologies was evaluated by bootstrap analysis (Felsenstein, 1985) based on 1000 resamplings of the neighbour-joining dataset using the CLUSTAL_X and MEGA4 packages. The $\mathrm{G}+\mathrm{C}$ content of the DNA was determined using the method of Mesbah et al. (1989).

Strain MN07-A0370 ${ }^{\mathrm{T}}$ was examined for key chemical markers to determine whether it had a chemotaxonomic profile consistent with its classification in the family Dermacoccaceae. The required biomass was harvested by scraping and centrifuging soft colonies from 7-day-old Bennett agar plates grown at $28{ }^{\circ} \mathrm{C}$. The harvested cell mass was washed twice with sterile distilled water and freeze dried. The whole-cell sugars, isoprenoid quinones, phospholipids and cellular fatty acids were analysed as described by Staneck \& Roberts (1974), Minnikin et al. (1984) and Tamura et al. (1994). The diaminopimelic acid $\left(\mathrm{A}_{2} \mathrm{pm}\right)$ isomer in the cellwall peptidoglycan was analysed as described by Nozawa $e t$ al. (2007). Cell-wall amino acids and mycolic acids were analysed as described by Tamura et al. (1994).

It is evident from Fig. 1 that strain MN07-A0370 ${ }^{\mathrm{T}}$ formed a distinct clade in the 16S rRNA gene sequence tree for the family Dermacoccaceae and clustered with the genera Demetria, Dermacoccus and Kytococcus; this association was supported by all of the tree-making algorithms and by a bootstrap value of about $60 \%$ in the neighbour-joining analysis. The similarity values of the $16 \mathrm{~S}$ rRNA gene sequences between strain MN07-A0370 ${ }^{\mathrm{T}}$ and members of the genera Kytococcus, Demetria and Dermacoccus ranged from $93.7 \%$ to $96.4 \%$.

Strain MN07-A0370 ${ }^{\mathrm{T}}$ formed circular, convex, smooth colonies that were pale yellow to bright yellow on Bennett agar after 1 week of incubation at $28{ }^{\circ} \mathrm{C}$ (see

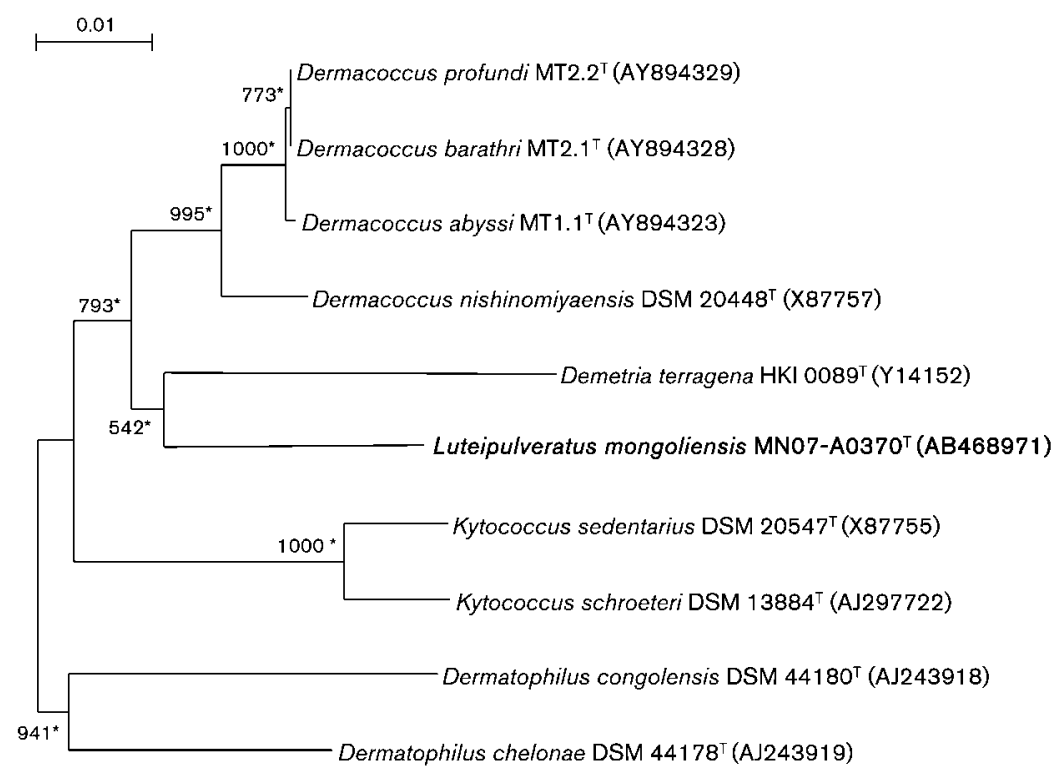

Fig. 1. Phylogenetic tree based on $16 \mathrm{~S}$ rRNA gene sequences constructed with the neighbour-joining algorithm showing the relationships between strain MN07-A0370 ${ }^{\top}$ and members of the family Dermacoccaceae. Asterisks indicate that the corresponding nodes were also recovered in trees generated with the minimum-evolution and maximumparsimony tree-making algorithms. Values at nodes are levels of bootstrap support based on 1000 resamplings. Dermatophilus congolensis DSM $44180^{\top}$ and Dermatophilus, chelonae DSM $44178^{\top}$ of the family Dermatophilaceae were used as the outgroups. Bar, 0.01 nucleotide substitutions per nucleotide position. 
Supplementary Table S1 in IJSEM Online). The cells occurred singly or in pairs, short chains or irregular clusters when grown on Bennett agar (Fig. 2a, b). Creamwhite to bright yellow smooth colonies with soft powdery surfaces were formed on ISP 3, 4, 5 and 7. Scanning electron microscopic observations revealed irregular coccoid- to short rod-shaped cells that varied in size $(0.5 \times 1.0-0.8 \times 1.2 \mu \mathrm{m})$ on Bennett agar. Rudimentary short aerial mycelium-like structures were found on ISP 4 (Fig. 2c, d). The physiological and biochemical properties of strain MN07-A $0370^{\mathrm{T}}$ are listed in the genus and species descriptions and in Table 1. The temperature range for growth on Bennett agar was $10-30{ }^{\circ} \mathrm{C}$ (optimum 20$28{ }^{\circ} \mathrm{C}$ ) and no growth was observed at $37{ }^{\circ} \mathrm{C}$. The isolate grew well with up to $2.0 \%(\mathrm{w} / \mathrm{v}) \mathrm{NaCl}$ and poorly with $3.0 \% \mathrm{NaCl}$ on Bennett agar medium. The physiological and biochemical properties of strain $\mathrm{MN} 07-\mathrm{A} 0370^{\mathrm{T}}$ that differentiate it from the recognized species of the genus Dermacoccus are colony colour, morphology, urea decomposition, hydrolysis of gelatin and starch, degradation of Tween 80 , nitrate reduction, enzyme activities such as $\alpha$ fucosidase, $\beta$-glucosidase, lipase (C14) and trypsin, growth at 10,37 and $40{ }^{\circ} \mathrm{C}$, little growth with $3.0 \% \mathrm{NaCl}$ and no growth with 4.0, 10.0 and $12.5 \% \mathrm{NaCl}$ (Table 1).

The cell-wall peptidoglycan of strain MN07-A0370 ${ }^{\mathrm{T}}$ contained L-lysine, alanine, aspartic acid, glutamic acid and serine in a molar ratio of $0.8: 2.7: 0.6: 1.0: 0.9$, respectively, which represented peptidoglycan type $\mathrm{A} 4 \alpha$. The predominant menaquinones were MK- $8\left(\mathrm{H}_{4}\right)(49.0 \%)$ and MK-8 $\left(\mathrm{H}_{6}\right)(48.8 \%)$ and this differed from those of other genera in the family Dermacoccaceae (Stackebrandt et al., 1995; Groth et al., 1997a). Lysine as the diagnostic diamino acid is mainly associated with coryneform and nocardioform morphologies. In sporoactinomycetes, lysine is found only in the genera Catenuloplanes (Yokota et al., 1993) and Couchioplanes (Tamura et al., 1994). To date, all known lysine-containing genera of actinomycetes have group-A peptidoglycan, with the exception of the genus Microbacterium, which possesses group-B peptidoglycan (Schleifer \& Kandler, 1972). Diamino acids in combination with menaquinone types are extremely useful in differentiating genera of coryneform bacteria from each other. The combination of menaquinone MK- $8\left(\mathrm{H}_{4}\right)$ plus MK- $8\left(\mathrm{H}_{6}\right)$ and lysine in the cell wall is unique in the family Dermacoccaceae. However, the presence of the menaquinone type $\mathrm{MK}-8\left(\mathrm{H}_{4}\right)$ and lysine has been reported for Demetria terragena in the family Dermacoccaceae and Bogoriella caseilytica in the family Bogoriellaceae (Groth et al., 1997b). Phosphatidylglycerol, diphosphatidylglycerol and phosphatidylinositol were detected as total phospholipids, whereas phosphatidylcholine, phosphatidylethanolamine and some other phospholipids containing glucosamine were not detected (phospholipid type PI sensu Lechevalier et al., 1977). The strain contained galactose, mannose, rhamnose, ribose and glucose as whole-cell sugars. Mycolic acids were not present. The fatty acid profile was characterized by the occurrence of large amounts of saturated iso- and anteiso-branched-chain fatty acids as well as smaller amounts of saturated straightchain and unsaturated acids. The fatty acid composition of strain MN07-A0370 ${ }^{\mathrm{T}}$ was iso- $\mathrm{C}_{16: 0}(45.8 \%)$, anteiso- $\mathrm{C}_{17: 0}$ $(7.9 \%)$, iso- $\mathrm{C}_{16: 1} \mathrm{H}(7.6 \%), \mathrm{C}_{17: 1} \omega 9 \mathrm{c}(7.3 \%), \mathrm{C}_{17: 0}$ 10-methyl (6.4\%), $\mathrm{C}_{17: 0}(4.0 \%)$, anteiso- $\mathrm{C}_{17: 1} \mathrm{C}(2.5 \%)$, iso- $\mathrm{C}_{18: 0}(2.4 \%), \mathrm{C}_{17: 0} \quad(2.3 \%), \mathrm{C}_{16: 0}(2.1 \%), \mathrm{C}_{16: 0}$ 10-methyl (2.0\%), $\mathrm{C}_{18: 0} \quad(1.6 \%), \quad \mathrm{C}_{16: 1} \omega 9 c \quad(1.5 \%)$, $\mathrm{C}_{18: 1} \omega 9 \mathrm{c}(1.2 \%)$, iso- $\mathrm{C}_{17: 0}(1.1 \%)$, iso- $\mathrm{C}_{14: 0}(0.8 \%)$, $\mathrm{C}_{15: 0}(0.7 \%)$, iso- $\mathrm{C}_{15: 0}(0.4 \%)$, anteiso- $\mathrm{C}_{15: 0}(0.4 \%)$, $\mathrm{C}_{18: 0} 10$-methyl $(0.4 \%)$ and $\mathrm{C}_{15: 1} \mathrm{~B}(0.4 \%)$. The $\mathrm{G}+\mathrm{C}$ content of the DNA of strain MN07-A0370 ${ }^{\mathrm{T}}$ was $68.2 \mathrm{~mol} \%$. Therefore, on the basis of differential chemotaxonomic characteristics (Table 1), especially for the peptidoglycan type with L-lysine in combination with the menaquinone components MK- $8\left(\mathrm{H}_{4}\right)$ and MK- $8\left(\mathrm{H}_{6}\right)$,
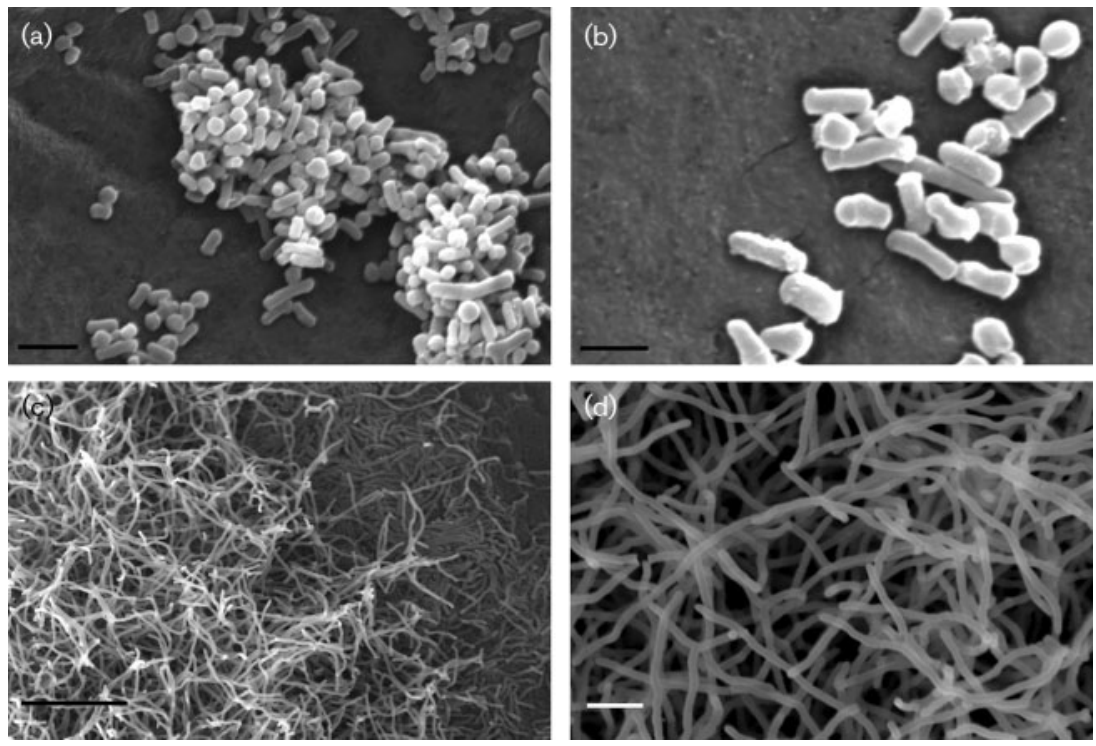

Fig. 2. Scanning electron micrographs of irregular coccoid- to short rod-shaped cells from 1-week-old cultures of strain MN07$\mathrm{A} 0370^{\top}$ grown on Bennett agar $(\mathrm{a}, \mathrm{b})$ and short, sterile and rudimentary aerial myceliumlike formation grown on ISP 4 agar (c, d) for 1 week at $28^{\circ} \mathrm{C}$. Bars, $2 \mu \mathrm{m}(\mathrm{a}, \mathrm{d})$ and $1 \mu \mathrm{m}$ (b, c). 
Table 1. Characteristics that differentiate strain $M N 07-A 0370^{\top}$ from the type strains of species of the closely related genera Dermacoccus, Demetria and Kytococcus in the family Dermacoccaceae

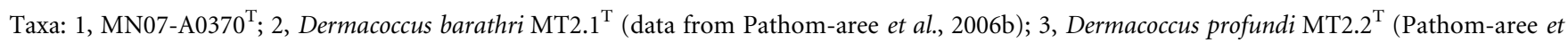
al., 2006b); 4, Dermacoccus abyssi MT1.1 ${ }^{\mathrm{T}}$ (Pathom-aree et al., 2006a); 5, Dermacoccus nishinomiyaensis DSM 20448 ${ }^{\mathrm{T}}$ (Stackebrandt et al., 1995; Kocur et al., 1975); 6, Demetria terragena HK1 $0089^{\mathrm{T}}$ (Groth et al., 1997a, b); 7, Kytococcus sedentarius DSM 20547 ${ }^{\mathrm{T}}$ (Becker et al., 2002; Stackebrandt et al., 1995); 8, Kytococcus schroeteri DSM $13884^{\mathrm{T}}$ (Becker et al., 2002). All taxa were positive for the presence of lysine in the cell wall and catalase activity. +, Positive; \pm , weakly positive; -, negative; ND, no data available; ai, anteiso-methyl branched; i, iso-methyl branched; DPG, diphosphatidylglycerol; PE, phosphatidylethanolamine; PG, phosphatidylglycerol; PI, phosphatidylinositol; PL, unknown phospholipid(s).

\begin{tabular}{|c|c|c|c|c|c|c|c|c|}
\hline Characteristic & 1 & 2 & 3 & 4 & 5 & 6 & 7 & 8 \\
\hline $\begin{array}{l}\text { Spore } \\
\text { morphology }\end{array}$ & $\begin{array}{l}\text { Coccoid to short rod-shaped } \\
\text { spores with rudimentary, } \\
\text { short aerial mycelium-like } \\
\text { formation }\end{array}$ & Coccoid & Coccoid & Coccoid & Coccoid & $\begin{array}{l}\text { Irregular coccoid to } \\
\text { short rod-shaped } \\
\text { spores with } \\
\text { filopodia }\end{array}$ & Coccoid & Coccoid \\
\hline \multicolumn{9}{|c|}{ Decomposition of: } \\
\hline Hypoxanthine & + & + & + & + & ND & - & ND & ND \\
\hline \multicolumn{9}{|l|}{ Hydrolysis of: } \\
\hline Arbutin & + & - & - & + & - & ND & ND & ND \\
\hline Gelatin & + & - & - & - & + & - & + & + \\
\hline \multicolumn{9}{|l|}{ API ZYM } \\
\hline$\alpha$-Fucosidase & \pm & + & - & + & + & - & ND & $\mathrm{ND}$ \\
\hline$\beta$-Glucosidase & - & + & - & + & + & - & $\mathrm{ND}$ & ND \\
\hline Lipase (C14) & - & + & - & + & + & \pm & $\mathrm{ND}$ & $\mathrm{ND}$ \\
\hline Trypsin & + & + & + & - & + & \pm & ND & $\mathrm{ND}$ \\
\hline \multicolumn{9}{|l|}{ Growth at/on: } \\
\hline $10{ }^{\circ} \mathrm{C}$ & + & + & + & + & - & ND & $\mathrm{ND}$ & $\mathrm{ND}$ \\
\hline $37^{\circ} \mathrm{C}$ & - & + & + & + & + & - & + & + \\
\hline $40{ }^{\circ} \mathrm{C}$ & - & - & - & - & ND & - & + & + \\
\hline $3.0 \% \mathrm{NaCl}$ & \pm & + & + & + & + & + & + & + \\
\hline $4.0 \% \mathrm{NaCl}$ & - & + & + & + & + & + & + & + \\
\hline $10.0 \% \mathrm{NaCl}$ & - & + & + & + & - & \pm & + & + \\
\hline Phospholipids & DPG, PG, PI & $\begin{array}{l}\text { DPG, } \\
\text { PG, PI }\end{array}$ & $\begin{array}{l}\text { DPG, } \\
\text { PG, PI }\end{array}$ & $\begin{array}{l}\text { DPG, } \\
\text { PG, PI }\end{array}$ & $\begin{array}{l}\text { DPG, } \\
\text { PG, PI }\end{array}$ & $\begin{array}{c}\text { DPG, PG, PI, } \\
\text { PE, PL }\end{array}$ & $\begin{array}{l}\text { DPG, } \\
\text { PG, PI }\end{array}$ & $\mathrm{ND}$ \\
\hline $\begin{array}{l}\text { DNA G }+\mathrm{C} \\
\text { content }(\mathrm{mol} \%)\end{array}$ & 68.2 & 66.8 & 69.1 & 65.2 & $66.0-71.0$ & 66.0 & $68.0-69.0$ & ND \\
\hline
\end{tabular}

strain MN07-A0370 ${ }^{\mathrm{T}}$ can be clearly separated from its closest phylogenetic neighbours and from all of the abovementioned genera that contain lysine in the cell wall.

The closest phylogenetic neighbours of strain MN07$\mathrm{A} 0370^{\mathrm{T}}$ are Dermacoccus barathri MT2.1 ${ }^{\mathrm{T}}$, Dermacoccus abyssi MT1.1 $1^{\mathrm{T}}$ and Dermacoccus profundi MT2.2 $2^{\mathrm{T}}$ (16S
rRNA gene sequence similarity $96.4 \%$ ), all of which differed from the new isolate in the amino acids of the interpeptide bridge, the predominant menaquinones and the major fatty acids, as well as in physiological, cultural and biochemical characteristics (Table 1). Furthermore, morphological differences justify the separation of strain MN07-A0370 ${ }^{\mathrm{T}}$ from the genus Dermacoccus. Pronounced 
differences in chemotaxonomic, morphological and physiological properties were also found between strain MN07-A0370 ${ }^{\mathrm{T}}$ and Demetria terragena (Table 1). Therefore, we conclude that on the basis of our results and the remarkable differences in taxonomic characteristics between strain MN07-A0370 ${ }^{\mathrm{T}}$ and all of the genera in the family Dermacoccaceae, strain MN07-A0370 ${ }^{\mathrm{T}}$ should be assigned to a novel species in a new genus, for which the name Luteipulveratus mongoliensis gen. nov., sp. nov. is proposed.

\section{Description of Luteipulveratus gen. nov.}

Luteipulveratus (Lu.te.i.pul.ve.ra'tus. L. adj. luteus yellow; L. part. adj. pulveratus scattered with dust; N.L. masc. n. Luteipulveratus a bacterium forming white powdery aerial mycelium on yellow colonies).

Cells are Gram-positive, irregular coccoid- to short rodshaped $(0.5 \times 1.0-0.8 \times 1.2 \mu \mathrm{m})$, and occur singly or in pairs, in short chains or small irregular clusters. Cells are non-motile and non-sporulating. Colonies are circular, convex, entire, smooth, $1.0-3.5 \mathrm{~mm}$ in diameter and pale yellow to bright yellow on Bennett agar. A rudimentary white and sterile powdery aerial mycelium-like structure is formed on ISP 3, 4, 5 and 7 agars after 1 week of incubation at $28{ }^{\circ} \mathrm{C}$. Growth is aerobic and catalase-positive. The cellwall peptidoglycan contains L-lysine, alanine, aspartic acid, glutamic acid and serine and represents peptidoglycan type A4 $\alpha$. Phospholipids are phosphatidylglycerol, diphosphatidylglycerol and phosphatidylinositol and the whole-cell sugars are galactose, mannose, rhamnose, ribose and glucose. Mycolic acids are absent. The fatty acid profile is characterized by the large amounts of saturated iso- and anteiso- branched-chain as well as smaller amounts of saturated straight-chain and unsaturated acids. The major fatty acids are iso- $\mathrm{C}_{16: 0}$, anteiso- $\mathrm{C}_{17: 0}$, iso- $\mathrm{C}_{16: 1} \mathrm{H}$, $\mathrm{C}_{17: 1} \omega 9 c$ and $\mathrm{C}_{17: 0}$ 10-methyl. The menaquinones are MK- $8\left(\mathrm{H}_{4}\right)$ and MK- $8\left(\mathrm{H}_{6}\right)$. Phylogenetically, this genus is a member of the family Dermacoccaceae. The type species is Luteipulveratus mongoliensis.

\section{Description of Luteipulveratus mongoliensis sp. nov.}

L. mongoliensis (mon.go.li.en'sis. N.L. masc. adj. mongoliensis pertaining to soil from Mongolia).

Morphological, chemotaxonomic and general characteristics are as given above for the genus description. Good growth occurs on Bennett agar, yeast-starch agar and ISP 2, 3, 4, 5, 6 and 7 agars. Production of bright yellow, watersoluble pigments is positive on Bennett and yeast-starch agar after 1 week of incubation. The optimal growth temperature is $20-28{ }^{\circ} \mathrm{C}$; no growth at $37{ }^{\circ} \mathrm{C}$. Grows well with up to $2.0 \%(\mathrm{w} / \mathrm{v}) \mathrm{NaCl}$; no growth with $>3.0 \% \mathrm{NaCl}$. Catalase is produced; nitrates are not reduced; gelatin is hydrolysed; starch is poorly hydrolysed; Tween 20, urea and arbutin are hydrolysed, but not Tween 80. Casein, calcium malate, tyrosine and hypoxanthine are decomposed, but not xanthine or adenine. According to the API ZYM enzyme assay, positive for alkaline phosphatase, esterase lipase (C8), leucine arylamidase, trypsin, acid phosphatase, $\alpha$-glucosidase, $N$-acetyl- $\beta$-glucosaminidase and $\alpha$-mannosidase. Weakly positive for $\alpha$-chymotrypsin, naphthol-AS-BI-phosphohydrolase, $\beta$-galactosidase and $\alpha$ fucosidase; negative for esterase (C4), lipase (C14), valine arylamidase, cystine arylamidase, $\alpha$-galactosidase, $\beta$-glucuronidase and $\beta$-glucosidase. According to the API Coryne enzyme assay, positive for catalase, alkaline phosphatase, pyrazinamidase, $\beta$-galactosidase, $\alpha$-glucosidase and $N$-acetyl- $\beta$-glucosaminidase; negative for nitrate reduction, pyrrolidonyl arylamidase and $\beta$-glucuronidase. According to the API $50 \mathrm{CH}$ test, positive for acid from glucose, maltose and sucrose; negative for acid from ribose, xylose, mannitol, lactose and glycogen. The predominant fatty acids are iso- $\mathrm{C}_{16: 0}$, anteiso- $\mathrm{C}_{17: 0}$, iso- $\mathrm{C}_{16: 1} \mathrm{H}$, $\mathrm{C}_{17: 1} \omega 9 \mathrm{c}$ and $\mathrm{C}_{17: 0}$ 10-methyl, with small amounts of

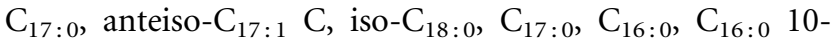
methyl, $\mathrm{C}_{18: 0}, \mathrm{C}_{16: 1} \omega 9 c, \mathrm{C}_{18: 1} \omega 9 c$, iso- $\mathrm{C}_{17: 0}$, iso- $\mathrm{C}_{14: 0}$, $\mathrm{C}_{15: 0}$, iso- $\mathrm{C}_{15: 0}$, anteiso- $\mathrm{C}_{15: 0}, \mathrm{C}_{18: 0} 10$-methyl and $\mathrm{C}_{15: 1} \mathrm{~B}$.

The type strain is MN07-A0370 ${ }^{\mathrm{T}}$ (=NBRC $105296^{\mathrm{T}}$ $=$ VTCC D9 $-09^{\mathrm{T}}$ ), which was isolated from grassland soil in Mongolia. The DNA G $+\mathrm{C}$ content of the type strain is $68.2 \%$.

\section{Acknowledgements}

This work was conducted under the Joint Research Project between the Department of Biotechnology, NITE, Japan and the Institute of Biology, Mongolian Academy of Sciences, Mongolia. We acknowledge Dr Tomohiko Tamura for scientific discussions and Ms Yayoi Sakiyama for technical assistance. We are grateful to Dr J. P. Euzéby for help with the nomenclature of the new genus.

\section{References}

Becker, K., Schumann, P., Wullenweber, J., Schulte, M., Well, H. P., Stackebrandt, E., Peters, G. \& Von Eiff, C. (2002). Kytococcus schroeteri sp. nov., a novel Gram-positive actinobacterium isolated from a human clinical source. Int J Syst Evol Microbiol 52, 16091614.

Cordero, M. R. \& Zumalacarregui, J. M. (2000). Characterization of Micrococcaceae isolated from salt used for Spanish dry-cured ham. Lett Appl Microbiol 31, 303-306.

De la Rosa, M. C., Mohino, M. R., Mohino, M. \& Mosso, M. A. (1990). Characteristics of micrococci and staphylococci isolated from semipreserved meat products. Food Microbiol 7, 207-215.

Eck, R. V. \& Dayhoff, M. O. (1966). Atlas of Protein Sequences and Structure. Silver Springs, MD: National Biomedical Research Foundation.

Felsenstein, J. (1985). Confidence limits on phylogenies: an approach using the bootstrap. Evolution 39, 783-791.

Groth, I., Schumann, P., Rainey, F. A., Martin, K., Schuetze, B. \& Augsten, K. (1997a). Demetria terragena gen. nov., sp. nov., a new genus of actinomycetes isolated from compost soil. Int J Syst Bacteriol 47, 1129-1133. 
Groth, I., Schumann, P., Rainey, F. A., Martin, K., Schuetze, B. \& Augsten, K. (1997b). Bogoriella caseilytica gen. nov., sp. nov., a new alkaliphilic coryneform bacteria from a soda lake in Africa. Int J Syst Bacteriol 47, 788-794.

Hayakawa, M. \& Nonomura, H (1987). Humic acid-vitamin agar, a new medium for selective isolation of soil actinomycetes. J Ferment Technol 65, 501-509.

Hayakawa, M., Otoguro, M., Takeuchi, T., Yamazaki, T. \& limura, Y. (2000). Application of a method incorporating differential centrifugation for selective isolation of motile actinomycetes in soil and plant litter. Antonie van Leeuwenhoek 78, 171-185.

Jones, K. L. (1949). Fresh isolates of actinomycetes in which the presence of sporogenous aerial mycelia is a fluctuating characteristic. J Bacteriol 57, 141-145.

Kocur, M., Schleifer, K. H. \& Kloos, W. E. (1975). Taxonomic status of Micrococcus nishinomiyaensis Oda 1935. Int J Syst Bacteriol 25, 290-293.

Lechevalier, M. P., DeBièvre, C. \& Lechevalier, H. A. (1977). Chemotaxonomy of aerobic actinomycetes: phospholipid composition. Biochem Syst Ecol 5, 249-260.

Marmur, J. (1961). A procedure for the isolation of deoxyribonucleic acid from microorganisms. J Mol Biol 3, 208-218.

Mesbah, M., Premachandran, U. \& Whitman, W. B. (1989). Precise measurement of the $\mathrm{G}+\mathrm{C}$ content of deoxyribonucleic acid by highperformance liquid chromatography. Int J Syst Bacteriol 39, 159-167.

Minnikin, D. E., O'Donnell, A. G., Goodfellow, M., Alderson, G., Athalye, M., Schaal, A. \& Parlett, J. H. (1984). An integrated procedure for the extraction of bacterial isoprenoid quinones and polar lipids. J Microbiol Methods 2, 233-241.

Norovsuren, Zh., Zenova, G. M. \& Mosina, L. V. (2007). Actinomycetes in the rhizosphere of semidesert soils of Mongolia. Eurasian Soil Sci 40, 415-418.

Nozawa, Y., Sakai, N., Arai, K., Kawasaki, Y. \& Harada, K. (2007). Reliable and sensitive analysis of amino acids in the peptidoglycan of actinomycetes using the advance Marfey's method. J Microbiol Methods 70, 306-311.

Papamanoli, E., Kotzekidou, P., Tzanetakis, N. \& LitopoulouTzanetaki, E. (2002). Characterization of Micrococcaceae isolated from dry fermented sausage. Food Microbiol 19, 441-449.

Pathom-aree, W., Nogi, Y., Sutcliffe, I. C., Ward, A. C., Horikoshi, K., Bull, A. T. \& Goodfellow, M. (2006a). Dermacoccus abyssi sp. nov., a piezotolerant actinomycete isolated from the Mariana Trench. Int $J$ Syst Evol Microbiol 56, 1233-1237.

Pathom-aree, W., Nogi, Y., Ward, A. C., Horikoshi, K., Bull, A. T. \& Goodfellow, M. (2006b). Dermacoccus barathri sp. nov. and Dermacoccus profundi sp. nov., novel actinomycetes isolated from deep-sea mud of the Mariana Trench. Int J Syst Evol Microbiol 56, 2303-2307.
Rzhetsky, A. \& Nei, M. (1992). A simple method for estimating and testing minimum-evolution trees. Mol Biol Evol 9, 945-967.

Saito, H. \& Miura, K. (1963). Preparation of transforming deoxyribonucleic acid by phenol treatment. Biochim Biophys Acta 72, 619629.

Saitou, N. \& Nei, M. (1987). The neighbor-joining method: a new method for reconstructing phylogenetic trees. Mol Biol Evol 4, 406425.

Schleifer, K. H. \& Kandler, O. (1972). Peptidoglycan types of bacterial cell walls and their taxonomic implications. Bacteriol Rev 36, 407-477.

Shirling, E. B. \& Gottlieb, D. (1966). Methods for characterization of Streptomyces species. Int J Syst Bacteriol 16, 313-340.

Stackebrandt, E. \& Schumann, P. (2000). Description of Bogoriellaceae fam. nov., Dermacoccaceae fam. nov., Rarobacteriaceae fam. nov. and Sanguibacteraceae fam. nov. and emendation of some families of the suborder Micrococcineae. Int J Syst Evol Microbiol 50, 1279-1285.

Stackebrandt, E., Koch, C., Gvozdiak, O. \& Schumann, P. (1995). Taxonomic dissection of the genus Micrococcus: Kocuria gen. nov., Nesterenkonia gen. nov., Kytococcus gen. nov., Dermacoccus gen nov., and Micrococcus Cohn 1872 gen. emend. Int J Syst Bacteriol 45, 682692.

Staneck, J. L. \& Roberts, G. D. (1974). Simplified approach to identification of aerobic actinomycetes by thin-layer chromatography. Appl Microbiol 28, 226-231.

Tamura, T. \& Hatano, K. (2001). Phylogenetic analysis of the genus Actinoplanes and transfer of Actinoplanes minutisporangius Ruan et al. 1986 and 'Actinoplanes aurantiacus' to Cryptosporangium minutisporangium comb. nov. and Cryptosporangium aurantiacum sp. nov. Int $J$ Syst Evol Microbiol 51, 2119-2125.

Tamura, T., Nakagaito, Y., Nishii, T., Hasegawa, T., Stackebrandt, E. \& Yokota, A. (1994). A new genus of the order Actinomycetales, Couchioplanes gen. nov., with descriptions of Couchioplanes caeruleus (Horan and Brodsky 1986) comb. nov. and Couchioplanes caeruleus subsp. azureus subsp. nov. Int J Syst Bacteriol 44, 193-203.

Tamura, K., Nei, M. \& Kumar, S. (2004). Prospects of inferring very large phylogenies by using the neighbor-joining method. Proc Natl Acad Sci U S A 101, 11030-11035.

Tamura, K., Dudley, J., Nei, M. \& Kumar, S. (2007). MEGA4: Molecular evolutionary genetics analysis (MEGA) software version 4.0. Mol Biol Evol 24, 1596-1599.

Thompson, J. D., Gibson, T. J., Plewniak, F., Jeanmougin, F. \& Higgins, D. G. (1997). The CLUSTAL_X Windows interface: flexible strategies for multiple sequence alignment aided by quality analysis tools. Nucleic Acids Res 25, 4876-4882.

Yokota, A., Tamura, T., Hasegawa, T. \& Huang, L. H. (1993). Catenuloplanes japonicus gen. nov., sp. nov., nom. rev., a new genus of the order Actinomycetales. Int J Syst Bacteriol 43, 805-812. 